Original Research Paper

\title{
Operasionalisasi IBM SPSS 21 untuk Meningkatkan Kemampuan dan Keterampilan Olah Data Penelitian Mahasiswa
}

\author{
Jono Irawan ${ }^{1 *}$, A.A. Ayu Trisna Handayani ${ }^{1}$, Lalu Hasan Nasirudin Zohri ${ }^{1}$ \\ ${ }^{1}$ Program Studi Magister Pendidikan IPA, Pascasarjana Universitas Mataram, Indonesia
}

DOI: https://doi.org/10.29303/jpmpi.v4i2.660

Sitasi: Irawan, J., Handayani, A. A. A. T., \& Zohri, L. H. N. (2021). Operasionalisasi IBM SPSS 21 untuk Meningkatkan Kemampuan dan Keterampilan Olah Data Penelitian Mahasiswa. Jurnal Pengabdian Magister Pendidikan IPA, 4(2)

Article History

Received: 03 Februari 2021

Revised: 08 Maret 2021

Accepted: 06 April 2021

*Corresponding Author:

Jono Irawan,

Program Studi Magister

Pendidikan IPA, Pascasarjana

Universitas Mataram, Indonesia

Email: mr.jhon29@gmail.com

\begin{abstract}
Program pengabdian pada masyarakat ini bertujuan untuk mengenalkan dan mengoperasikan program IBM SPSS 21 kepada mahasiswa sebagai alat untuk mengolah data penelitian yang baik dan benar. Kegiatan dilakukan dengan metode diskusi bebas yang dimulai dengan penyampaian materi. Objek pelatihan adalah Mahasiswa Program Studi Pendidikan Kimia FKIP Dan Mahasiswa Magister Pendidikan IPA Universitas Mataram. Data hasil angket dianalisis dengan Descriptive Statistics Explore IBM SPSS 21. Hasil analisis data pengabdian diperoleh persentase pemahaman sebesar $60,4 \%$ dan keaktifan dalam proses pembelajaran sangat tinggi dengan persentase sebesar $83,2 \%$. Berdasrkan hasil analisis disimpulkan bahwa kegiatan pelatihan operasionalisasi program IBM SPSS 21 dan meningkatkan pemahaman dan keaktifan mahasiswa dalam menerapkan penggunaan program SPSS sebagai sarana mengolah data penelitian.
\end{abstract}

Keywords: Statistika; IBM SPSS 21; Keterampilan Olah Data

\section{Pendahuluan}

Penelitian adalah suatu kegiatan ilmiah yang wajib dilakukan mahasiswa pada perguruan tinggi sebagai suatu usaha untuk menemukan, mengembangkan, dan menguji kebenaran suatu pengetahuan (Suharsimi, 2006). Penelitian melatih mahasiswa untuk lebih tanggap terhadap lingkungan sekitarnya, baik lingkungan tempat tinggal maupun lingkungan pendidikan. Mahasiswa mengamati permasalahan-permasalahan dalam lingkungan pendidikan terutama pada lingkungan sekolah. mulai dari kegiatan kebijakan, kegiatan guru dalam mengajar, kemampuan belajar, minat belajar dan bahan penunjang dalam pembelajaran sehari-hari di sekolah.
Permasalahan tersebut menjadi perhatian setiap peneliti dalam memperbaiki mutu pendidikan. Terutama mahasiswa yang merupakan akademisi yang diharapkan mampu mmebuat perubahan pada pendidikan di berbagai daerah.

Peneliti melakukan pengamatan dan perlakuan terhadap pembelajaran. Pengembangan perangkat pembelajaran sampai pada media penunjang dalam pembelajaran. Pengembangan yang dilakukan tentu membutuhkan indikator untuk mengetahui sejauh mana pengaruh terhadap perlakukan yang diberikan (Erawanto, 2016). Peneliti membuat instrumen untuk mengukur tingkat kemampuan dan kualitas dari bahan yang dikembangkan. Untuk mengetahui hasil yang dilakukan tentu perlu suatu proses uji yang 
menyatakan perangkat dan peningkatan kemampuan siswa telah tercapai atau treatment berpengaruh secara signifikan. Untuk memudahkan dalam menganalisis dan menentukan kesimpulan suatu pengaruh disebut dengan statistik.

Statisitk merupakan suatu alat yang digunakan peneliti dalam menyikapi suatu permasalahan. Statistika adalah ilmu yang mempelajari bagaimana caranya mengumpulkan data, menyederhanakan data, menyajikan data, dan membuat kesimpulan berdasarkan informasi yang diperoleh dari sampel (Rosana, 2016). Peneliti merumuskan permasalahan, mencari informasi faktor penyebab, melakukan percobaan untuk mengatasi, mengevaluasi dan menentukan keputusan terhadap permasalahan yang diamati. Tahapan-tahapan ini diatur dalam statistik. Statistik merupan metode ilmiah dalam mengatasi permasalahan yang hasilnya dapat diterima berdasarkan fakta-fakta ilmiah yang dihasilkan. Peran statistik sangat penting pada dunia penelitian. Konsep statistik harus dikuasai oleh peneliti disebabkan sangat menentukan terhadap hasil pengamatan dan sebagai bahan dasar evaluasi pada suatu masalah. Apabila konsep statistik tidak dipahami dengan benar maka akan terjadi miskonsep dalam pemecahan masalah dan pengambilan kebijakan dalam dunia pendidikan. Dalam memudahkan kerja analisis data dibutuhkan program analisis. Program yang biasa digunakan untuk analsis statistik adalah SPSS.

Prgram SPSS (Statistical Product and Service Solution) adalah suatu alat yang memudahan dalam proses analisis data penelitian. Program SPSS merupakan program yang dikhususkan untuk mengolah data statistik. Program ini dikenal sangat handal dalam membantu para peneliti untuk melakukan uji dan analisis statistik (Panjaitan \& Firmansyah, 2018). Peneliti tidak lagi dihambat oleh lama waktu proses analsis data. Peneliti bisa langsung memperoleh hasil dari data yang ingin diketahui. Namun, sebagian besar peneliti terutama pada program sarjana tidak memanfaatkan program SPSS dalam analisis data. Analisis masih dilakukan secara manual menggunakan microsoft excel. Penggunaan microsoft excel tentu membutuhkan waktu yang lama dikarenakan banyaknya data dan perhitungkan. Peneliti yang melakukan kesalahan dalam perhitungan akan mengulang kembali proses analisis jika tidak sesuai dengan yang diinginkan. Program SPSS membantuh peneliti menyajikan data dengan proses mudah dan cepat. Peneliti mudah melakukan pengulangan olah data jika terjadi kesalahan input data. Program SPSS yang berperan penting untuk memudahkan peneliti dalam menggunakan statistik dalam penelitian.

Pada kenyataannya, calon peneliti (mahasiswa) banyak yang masih belum memahami statistik. Konsep statistik belum digunakan dengan benar. Sebagain banyak yang menyepelekan sehingga tidak terlalu memperhatikan metodologi dan cara oleh data. Salah satu contoh adalah pengolahan data secara desktiptif, peneliti sudah berani menyimpulkan terhadap perlakukan yang dilakukan. Tentu hal ini sangat beresiko dalam pemecahan masalah dan perkembangan ilmu pengetahuan. Tiga unsur pokok yang paling mendasar dalam penelitian adalah metodologi, teknik sampling dan teknik analisis data hasil penelitian. Apabila terjadi kesalahan pada ketiga tahapan ini maka penelitian yang dilakukan menjadi tidak bermakna. Hal yang menjadi pondasi dalam penelitian tentu harus dikuasi dengan penuh agar tidak terjadi kesalahan pada proses penelitian dan hasil dapat diterima di kalangan masyarakat akademisi. Untuk menyikapi situasi seperti ini, penerapan pelatihan operasionalisasi SPPS diharapkan mampu meningkatkan kemampuan mahasiswa. Pelatihan SPSS berhasil meningkatkan $70 \%$ kemampuan mahasiswa dalam memahami dan menguasai SPSS (Ismail, 2019) serta pemahaman teori dan 
praktek tentang metode penelitian dan statistik (Fadmi, 2019). Peserta antusias dengan kegiatan pelatihan yang diadakan, hal ini dilihat dari keaktifan peserta pelatihan selama proses pelatihan berlangsung. Wijaya (2020) juga berhasil melakukan pelatihan program SPSS dan menunjukkan adanya peningkatan kemampuan guru-guru SMA di Provinsi DIY dalam memahami alat-alat statistik dan kemampuan mengolah data mmenggunakan program statistik.

Berdasarkan uraian di atas, maka diperlukan penekanan pemahaman konsep tentang statistik dan program yang memudahkan dalam mengolah data melalui kegiatan Pelatihan Operasionalisasi SPSS untuk Meningkatkan Kemampuan dan Keterampilan Mahasiswa Program Studi Kimia FKIP Universitas Mataram. Denagan kegiatan pengabdian ini, dihharapkan mahasiswa tidak melakukan kesalahan dalam metodologi penelitian. Fakta ilmiah yang dihasilkan dapat dipertanggungjawabkan kebenaran dan dapat dijadikan sebagai acuan dalam pengambilan kebijakan dengan meningkatkan mutu pendidikan.

\section{Metode}

a. Persiapan

Persiapan rencana program pengabdian pada mahasiswa akhir Pendidikan kimia tentang Pelatihan operasionalisasi SPSS 21 meliputi: persiapan materi pelatihan, mengurus surat izin pengadian, konsolidasi dengan mahasiswa Pendidikan kimia yang akan menjadi peserta sebagai kelompok masyarakat sasaran

b. Pelaksanaan

Metode yang akan digunakan dalam kegiatan pengabdian ini adalah sebagai berikut.

1. Pemberian Instrumen Pretest: dilakukan dengan mengirim link google form yang memuat instrument test pengetahuan dan keterampilan tentang operasionalisasi program SPSS melalui menu chat (obrolan) pada aplikasi zoom. Selanjutnya, panitia memberikan waktu sekitar 15 menit kepada peserta untuk menjawab instrument sebelum tahap selanjutnya dilaksanakan.

2. Sosialisasi dan Pelatiahan: Sosialisasi dan pelatihan operasinalisasi program SPSS dilaksanakan Ketika semua peserta telah selesai mengerjakan intrumen posttes. Peserta diarahkan membuaka program SPSS yang telah diberikan panitia sebelum kegiatan berlangsung. Selanjutnya, peserta mendengarkan penyampaian materi oleh pemateri dan melakukan Latihan operasionalisasi program SPSS sesuai arahan panitia.

3. Pemberian Instrumen Posttest: dilaksanakan dengan mengirim link google form yang memuat instrumen tes pengetahuan dan keterampilan tentang operasionalisasi program SPSS melalui menu chat pada aplikasi zoom. Selanjutnya, panitia memberikan waktu sekitar 15 menit kepada peserta untuk menjawab instrument sebelum kegiatan ditutup.

4. Analisis dan Interpretasi Data: dilaksanakan dengan mendownload data hasil jawaban peserta dari soal instrumen yang telah diberikan. Selanjutnya, data dianalisis secara deskriptif kemudian diinterpretasi menggunakan grafik agar memudahkan dalam menjelaskan perbedaan kemampuan peserta sebelum dan sesudah dilaksanakan sosialisasi dan pelatihan.

c. Teknik Pengumpulan dan Analisis Data

Teknik pengumpulan data dilakuan dengan melakukan survei, pretest dan postest. Data hasil angket dianalisis secara deskriptive statistics explore menggunakan program IBM SPSS 21 untuk memperoleh data rata-rata dan persentase peningkatan 
pemahaman setelah proses pelatihan berlangsung.

\section{Hasil dan Pembahasan}

Pengolahan data adalah salah satu bagian terpenting dalam mendukung studi dan pekerjaan. Hampir semua bagian melakukan pengumpulan, manajemen, dan pengolahan data untuk banyak hal, mulai dari pekerjaan administrasi, ketatausahaan, keuangan, pengolahan data penelitian, dan pengolahan data untuk keperluan lainnya. Oleh karena itu, aplikasi pengolahan data sangat diperlukan. Bagi pengelola perguruan tinggi, aplikasi pengolahan data akan berguna untuk mendukung pekerjaan sehari-hari dan bahan mentah untuk membangun sebuah sistem informasi. Sedangkan bagi mahasiswa, aplikasi data sebagai pengolah data akan berguna dalam banyak hal yaitu mahasiswa dapat menentukan kualitas informasi secara cepat, akurat, dan relevan.

Salah satu aplikasi pengolahan data yang sering digunakan saat ini adalah aplikasi SPSS (Statistical Product and Service Solution). Aplikasi SPSS (Statistical Product and Service Solution) adalah salah satu program atau aplikasi di bidang statistik yang mampu memproses data statistik secara cepat dan akurat. Aplikasi SPS menjadi sangat popular karena memiliki bentuk pemaparan yang baik (memiliki grafik dan tabel), bersifat dinamis (mudah dilakukan perubahan data), dan mudah dihubungkan dengan aplikasi lain dalam preparasi data sampel analisis.

Kegiatan pelatihan ini merupakan salah satu dari kegiatan pengabdian kepada masyarakat yang ditujukan kepada mahasiswa pada khususnya untuk membantu dalam melakukan analisa data penelitian tugas akhir. Pelaksanaan pelatihan pengolahan data menggunakan aplikasi SPSS dilaksanakan kepada mahasiswa Universitas Mataram. Waktu pelaksanaannya pada tanggal 21 Februari 2021, berlangsung pada pukul 10.00
WITA sampai 12.00 WITA, dengan dihadiri sekitar 24 orang mahasiswa sebagai peserta pelatihan. Pelatihan dilakukan setelah dilakukan survei terhadap kesediaan mengikuti pelatihan operasionalisasi program IBM SPSS 21 seperti pada gambar 1. Kegiatan yang dilakukan berupa penyampaian materi dan pelatihan langsung mengenai cara mengoperasikan program IBM SPSS 21 beserta cara menginterpretasikan hasil pengolahan data tersebut. Software SPSS pada awalnya singkatan dari "Statistical Package for the Social Sciences", yang semula digunakan bagi ilmu sosial saja dan seiring perkembangan software ini yang semakin meluas dalam hal penggunaannya, sehingga kepanjangan SPSS diubah menjadi "Statistical Product and Service Solutions" yaitu suatu aplikasi statistika mengelola dan menganalisis data menggunakan teknik statistika (Yusuf, 2009).

Pelatihan dilakukan untuk membantu mahasiswa dalam analisis data dari hasil penelitian yang dilakukan. Dalam membuat suatu keputusan terhadap suatu perlakukan tentu data harus diolah terlebih dahulu dengan baik dan benar sehingga yang disampaikan adalah hasil yang akurat dan sesuai dengan keadaan sebenarnya. Mahasiswa membutuhkan statistik untuk memenuhi hasil yang akurat. Statistik adalah mata kuliah yang pada umumnya dapatkan di bangku perkuliahan (Nainggolan et al. 2017), termasuk mahasiswa Pendidikan Kimia Universitas Mataram. Namun kendalanya, ketika berada di semester tingkat akhir mahasiswa mengalami kesulitan dalam melaksanakan penelitian saat mengolah dan menganalisis data statistika (Ismail dan Safitri, 2019). Sehingga kegiatan sosialisasi dan pelatihan analisis data statistika umumnya adalah solusi yang dilakukan untuk mengatasi kesulitan mahasiswa tersebut (Syaleh, 2020). 


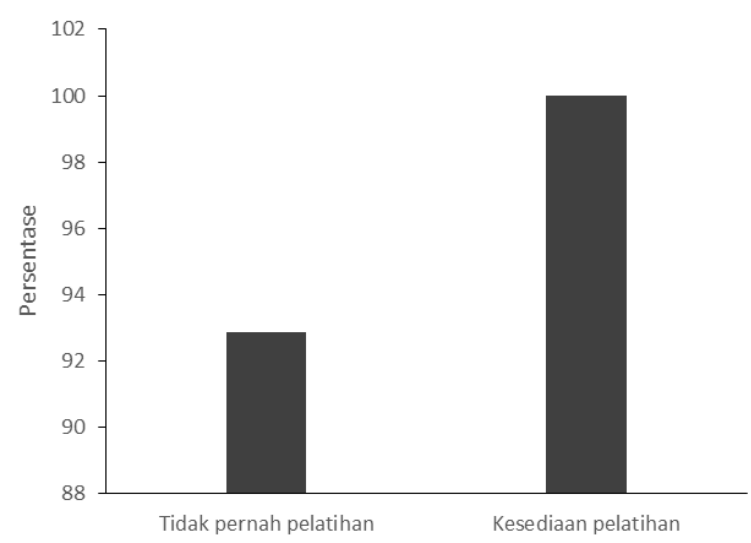

Gambar 1. Kesediaan mengikuti pelatihan

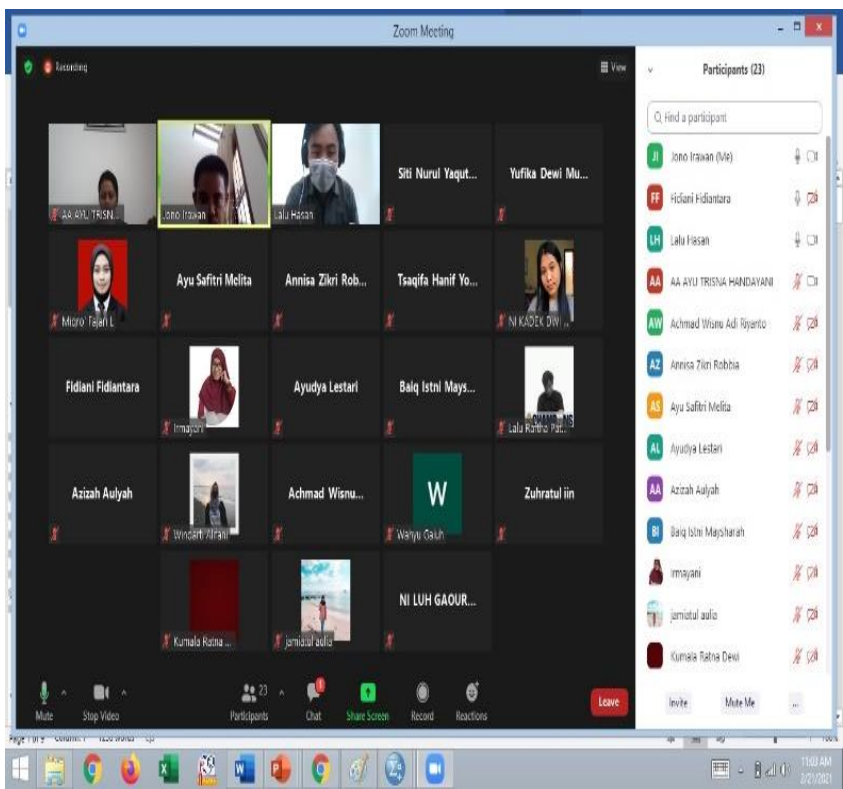

Gambar 2. Kegiatan Pelatihan operasionalisasi program, IBM SPSS 21

Sudjana (1992) mengartikan statistika sebagai pengetahuan yang berhubungan dengan cara-cara pengumpulan fakta, pengolahan serta penganalisisannya, penarikan kesimpulan serta pembuatan keputusan yang cukup beralasan berdasarkan fakta yang dilakukan. Oleh karena itu, statistika memberi pengaruh yang besar pada kajian ilmu lain seperti pendidikan, pertanian, kelautan dan perikanan dan bidang ilmu lainnya. Dalam menganalisis data statistika tidak dapat dilakukan tanpa melakukan teknik yang tepat. Artinya, analisis yang handal seharusnya menafaatkan keakurasian dan kecepatan perhitungan dengan paket komputasi statistika (statistical computing package). Contoh komputasi statistika yang sering digunakan dengan karakteristik yang berbeda-beda salah satunya SPSS (Pasaribu et al., 2018).

Simulasi pengolahan data dan teori statistik yang diberikan mampu membuat mahasiswa lebih memahami statistik dan teknik analisis data dengan program SPSS. Mahasiswa yang paham mengolah data dengan statistika dan SPSS mengalami peningkatan seperti pada gambar 3. Pemahaman penggunaan program SPSS mahasiswa meningkat sebesar 13,9\%. Berdasarkan persentase peningkatan pemahaman menunjukan bahwa, pelatihan penggunaan program IBM SPSS 21 dapat membantu mahasiswa menjadikan penelitiannya layak untuk dijadikan rujukan dalam pengmabilan keputusan dalam pengembangan pendidikan. Penggunaan Software SPSS dapat menganalisis data dalam jumlah besar, memiliki paket analisis data yang lebih bervariasi sehingga dapat meningkatkan efektifitas dan efisiensi dalam pengolahan data (Pasaribu et al., 2018).

Pelatihan menimbulkan efek yang positif pada mahasiswa. Mahasiswa lebih menyadari peranan statistikan dan penggunaan program SPSS dalam mengolah data penelitian. Kegiatan banyak diisi dengan diskusi dan tanya jawab. Kegiatan sangat interaktif yang diselenggarankan dengan diskusi terbuka. Peserta bisa menanggapi setiap saat jika tidak paham dengan materi yang disampaikan. Model pembelajaran seperti ini akan membuat mahasiswa lebih paham dikarenakan langsung memperoleh jawaban dari pemateri. Mahasiswa tidak miskonsepsi dengan penggunaan teknik analisis statistika pada data penelitian. Penggunaan uji-t dan uji lanjut untuk melihat pengaruh, uji anova dan uji lanjut dengan post hoc dan penggunaan uji anacova pada kuasi eksperimen. Pemahaman 
ini diperoleh tentu dengan antusias yang tinggi dalam peroses pelatihan (gambar 4).

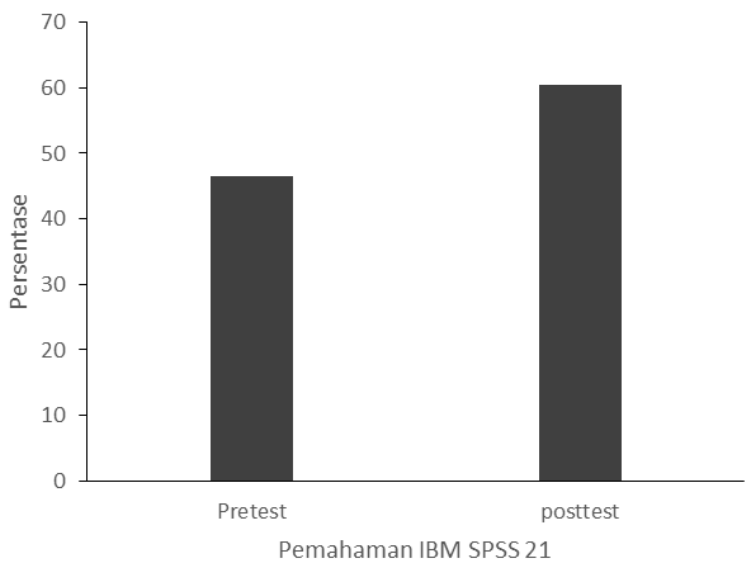

Gambar 3. Hasil pretest dan posttest pemahaman penggunaan SPSS

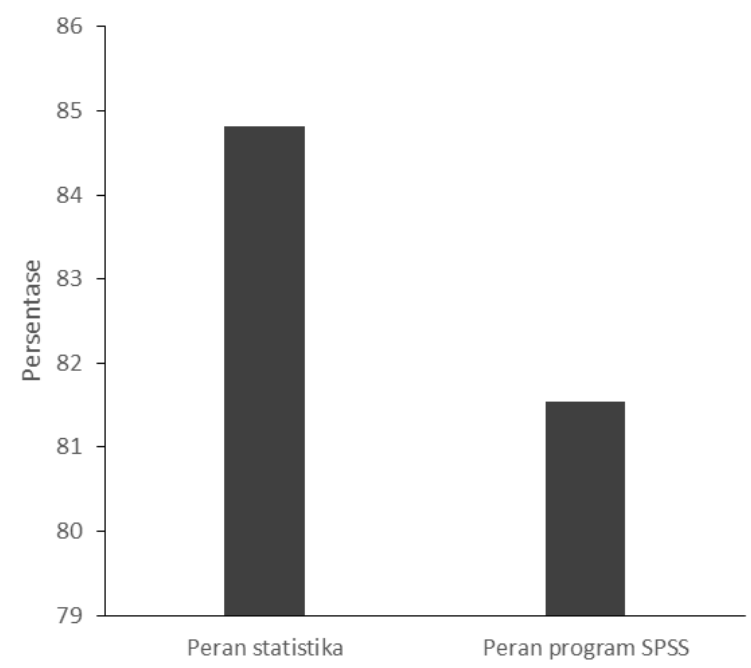

Gambar 4. Keaktifan mahasiswa dalam menanggapi peranan statistika dan program SPSS

\section{Kesimpulan}

Berdasarkan hasil analisis proses pelatihan operasionalisasi program IBM SPSS 21 dapat disimpulkan bahwa tingkat pemahaman mahasiswa tentang statistika lebih meningkat dengan simulasi program SPSS dan interpretasi data dari $46,4 \%$ menjadi $60,4 \%$.
Keaktifan mahasiswa juga sangat tinggi pada proses pembelajaran statistika dengan operasionalisasi program SPSS dengan ratarata persentase sebesar $83,2 \%$.

\section{Ucapan terima kasih}

Terima kasih kami sampaikan kepada Bapak Dr. Jamaluddin dan Bapak Dr. Abdul Syukur atas bimbingan mulai dari penyusunan proposal sampai pada tahap akhir program pengabdian.

\section{Daftar Pustaka}

Erawanto, U. (2016). Pengembangan modul pembelajaran berbasis masalah untuk membantu meningkatkan berfikir kreatif mahasiswa. JINoP (Jurnal Inovasi Pembelajaran), 2(2), 427-436.

Fadmi, F. R., \& Zulfadlih, L. S. (2019). Pelatihan Program Statistik Spss Bagi Guru Smk Kesehatan Di Kota Kendari. Miracle Journal of Public Health, 2(2), 162-168.

Ismail, R., \& Safitri, F. (2019). Peningkatan kemampuan analisa dan interpretasi data mahasiswa melalui pelatihan program SPSS. Jurnal Masyarakat Mandiri, 3(2), 148-155.

Ismail, R., \& Safitri, F. (2019). Peningkatan kemampuan analisa dan interpretasi data mahasiswa melalui pelatihan program SPSS. Jurnal Masyarakat Mandiri, 3(2), 148-155.

Nainggolan, E., Mariah, S., \& Kurniawan, F. (2017). Internalisasi Asumsi Pembelajaran Andragogi Pada Mata Kuliah Statistik. Jurnal Keluarga Sehat Sejahtera, 15(1).

Panjaitan, D. J., \& Firmansyah. (2018). Pelatihan Pengolahan Data Statistik dengan Menggunakan SPSS. Prosiding Seminar Nasional Hasil Pengabdian, 1(1), 40. 
Pasaribu, F. T., Multahadah, C., Febrianti, A., \& Asiani, R. W. (2018). Pelatihan peningkatan kemampuan analisis data penelitian menggunakan software SPSS bagi pemuda RT. 14 Perumnas Aurduri Indah Kota Jambi. Jurnal Karya Abdi Masyarakat, 2(1), 62-69.

Rosana, D., \& Setyawarno, D. (2016). Statistik terapan untuk penelitian pendidikan. Yogyakarta. Suherman, U.(2010). Konseling karir sepanjang rentan kehidupan. Bandung: UPI.

S. Yusuf, N. (2009). Penggunaan Software SPSS untuk Anlaisis Faktor Daya Beli Listrik pada Sektor Rumah Tangga dengan Metode Regresi Linear Berganda (Studi kasus Kota Salatiga). Simposium Nasional Rapi VIII. ISSN 1412-9612.

Sudjana (1992). Metode Statistik. Tarsito Bandung.

Suharsimi, A. (2006). metodelogi Penelitian. Yogyakarta: Bina Aksara.

Syaleh, H. (2020). Pelatihan Program Statistic Product and Service Solution (SPSS) bagi Mahasiswa dan Dosen Sekolah Tinggi Ilmu Ekonomi H. Agus Salim Bukittinggi. Community Engagement and Emergence Journal (CEEJ), 1(1), 14-21.

Wijaya, T (2020). Peningkatan Kemampuan Pengolahan Data Melalui Pelatihan Statistik dan Aplikasi Program SPSS bagi Guru-Guru SMA di DIY. To MAega: Jurnal Pengabdian Masyarakat, 3(1), 3135 